\title{
〔89]均一系での立体規則性重合における前末端基効果の 存在と重合条件との関係
}

(1966 年 2 月 25 日受理)

大隅行彦*·東村敏延* 岡村誠三*

\begin{abstract}
要 旨 $\operatorname{triad}$ のイソタクチック付加の確率 $\left(P_{i i}\right)$ とへテロタクチック付加の確萆 $\left(P_{s_{i}}\right)$ の比で定 義される $\alpha$ 值 $\left(P_{s_{i}} / P_{i i}\right)$ を用いて，メチルビニルエーテル(MVE)についての赛験結果，およびその 他の文献値から，均一采イオン機構による立体規則性央合の前末端基勃果を考察した。まず $\alpha$ 值と モノマーの種々の立体付加の自由エネルギーの差との関係が求められた。てして中条の取报）に基 いて, MVE のカチオン重合およびメタクリル酸エステルのアニオン重合において，前末端基効果 が实在することを明らかとした。イオン重合における前末端基効果が実在することが明らかになっ たので, 前末端基効果に対するモノマー, 触媒, および溶媒の種類の影響が検討された。溶媒の極 性によって $\alpha$ 值が変化する場合としない場合がある。これより前末端基効果には対イオンと前末端 甚の強い相互作用に基く場合と，対イオンに無閔係に前末端基のみに基く場合の両者が存在するこ とが推空学れた。
\end{abstract}

\section{1. 緒言}

ビニルモノマーの立体規則性重们が可能なためには， モノマーがなんらかの原因で立体的に規則正しく生長末 端に付加することが必要である。これを誘起与る原因と して，ポリマー側に原因があるとする末端規制と，触媒 側に不整中心を考える触媒規制の三つが考云られる11。 しかし反応系に均一に溶解し，活性中心が一つしか考兄 られないような簡単な触媒では，触媒側にモノアーの立 体規制の原因である不整中心を考えることは图難であ る。末端規制では生長末端の置換基とイオン対の構造 が, 次に入ってくるモノマーの立体構造を決めることに なる。この場合，生長末端のみでなく，その一つ前のモ ノマー単位 (penultimate unit, 前末端基) も攻整モノマー の立体楧造の規制に関与することがある。普通，これは 前末端基訤果 (penultimate effect) と呼ばれている。前末 端基効果については㮔々の統計的取扱が行なわ的ている が，实際に前末端基効果がいかなる条件で存在するふ・と いら実験的な面からの検討は行なわれていない。

わ礼わ机は前報2）に掂いて前末端基効果を示寸一つの 尺度として (1)式で表わされる $\alpha$ を定義した。

$$
\alpha=\frac{P_{s i}}{P_{i i}}
$$

ここで $P_{i i}$ はポリマー中のモノマー単位の立体構造を $d$ および $l$ で示した場合に，生長末端一 $-d d$ ，あるいは一 $l l$ にモノマーが $\boldsymbol{d}$ あるいは $l$ の構造で付加する確堔で る。同様に $P_{s i}$ は生長末端一一 $d l$, あるいは - $l d$ に $l$ あ るいは $d$ の構造にモノマーが付加する確染である。この ように定義すると，ポリマーの立体構造は $P_{i i}$ と $\alpha$ の値

* 京都大学工学部高分子化学教窒（京都市左京区占 田）
で決められることになる。

$\alpha$-メチルスチレン $(\alpha \mathrm{MS})$ の上うな無極性モノマーで

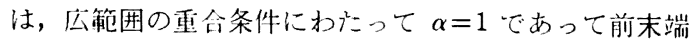
基効果は存在しない。他方メチルビニルエーテル(MVE) やメタクリル酸メチル(MMA)の上うな㥛性モノマーの イオン重合では $\alpha<1$ であった。そして，かなり異なる 重合条件でも，一定のモノマーに刘しては $\alpha$ はだいたい 一定の值を示すことなら，これら極性モノマーのイオン 重合では前末端基刘果が存在すると考えた。

前末端基效果を導入すると，上述のように $P_{i i}$ と $\alpha$ の 二つのパラメーターを用いてポリマーの立体構造が表わ さ机るが，パラメーターの多いことに基く不明確さが存 在する。 $\alpha \neq 1$ の場合には, ポリマーの立体構造に末端基 以外の影響があることがわかるが，それが前末端基効果 かそれ以外の効果であるかをこれだけでは判定できな い。中条3) はこの点について理論的な考察を行ない, 前 末端基効果の実在性についての明確な取扱を示した。

そ机ゆ六，本報告においては，まず前報でわれわれの

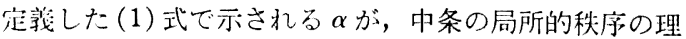
論から求めた付加の自由エネルギー差とどのような関係 にあるかを検討した。ついで実際の実験結果について， 前末端基効果の実在性とその重合条作との関係を議諭し た。

\section{2. $\alpha$ 值と付加の自由エネルギーとの関係}

上述のように，中条3) は Ising モデルによる取报で(), 前末端基滏果の有無を検討した。今, $\varepsilon$ をノマー $1 \mathrm{~mol}$ が各サフィックスの立体構造に付加する場合の自由エネ ルギーとすると (2) 式が得られる。ここでサフィックス $I, S$ 抽び $H$ はそ机ぞれアイソタクチック，シンジオ タクチックおよびへテロタクチックを意味し， $N_{i i} / N$, 


$$
\Delta \varepsilon=\varepsilon_{I}+\varepsilon_{S}-2 \varepsilon_{B}=-R T \ln \left\{\frac{4\left(\frac{N_{i i}}{N}\right)\left(\frac{N s s}{N}\right)}{\left(\frac{N_{s i}+N_{i s}}{N}\right)^{2}}\right\}
$$

$(N s s / N)$ および $\left(N_{s i}+N_{i s}\right) / N$ はそれぞれアイソタクチ ック，シンジオタクチックおよびへテロタクチック triad のモル分率を示す。また， $R$ 汾父体定数である。ここで $\Delta \varepsilon$ が 0 でなく, 重合温度 $T$ となんらかの直線闒係に あるときは前末端基勃果が突在寸ることが明ら放にされ た。

各 $\operatorname{triad}$ のフラクション $1, S$ および $H$ は $\alpha$ と $P_{i i}$ を 用いて (3) 式の関係で示されることを前報2)で示した。

$$
\left.\begin{array}{c}
I=\frac{N_{i i}}{N}=\frac{\alpha P_{i i}{ }^{2}}{1-(1-\alpha) P_{i i}} \\
S=\frac{N_{s s}}{N}=\frac{\left(1-P_{i i}\right)\left(1-\alpha P_{i i}\right)}{1-(1-\alpha) P_{i i}} \\
H=\frac{N_{s i}+N_{i s}}{N}=\begin{array}{c}
2 \alpha P_{i i}\left(1-P_{i i}\right) \\
1-(1-\alpha) P_{i i}
\end{array}
\end{array}\right\}
$$

この関倸を用いると(2)式の右辺の＼{\}の中は(4)式で示 } され，(2)式は(5)式となって $\alpha$ と $\Delta \varepsilon$ が簡単な関係で結 びつけられていることが扔る。今，P $P_{i i}$ と温度が一定で あれば， $\alpha$ が小さくなるにつれて (5) 式の（）内の分子 は大となり, $\Delta \varepsilon$ は負の大きな值となる。このことは前末 端基効果が大きいと $\alpha$ が小さくなり， $\Delta \varepsilon$ が負の大きい值 となることを示している。このように $\alpha$ と $\Delta \varepsilon$ は㷙末端 基効果について異なる表現をしていたものであることが 理解される。

$$
\begin{gathered}
\frac{4 I S}{H}=\frac{\frac{1}{\alpha}-P_{i i}}{1-P_{i i}} \\
\Delta \varepsilon=\varepsilon_{I}+\varepsilon_{S}-2 \varepsilon_{B}=-R T \ln \left\{\frac{\frac{1}{\alpha}-P_{i i}}{1-P_{i i}}\right\}
\end{gathered}
$$

ここてシンジオタクチック付加の前末端基効果を直観 的に見やすいように， $\alpha$ と同栚に(6)式で定我されるパラ メーター $\beta$ 導入する。

$$
\beta=\frac{P_{i s}}{P_{s s}}
$$

(6)式から見られるように, $\beta$ が 1 より小さいこはシ シジオタクチック緗众の次にはシンジオタクチック付加 が起こりがすいことを意味している。しかし，ここで $\beta$ は独立な变数でなく, $P_{i s}$ と $P_{s s}$ が $\alpha$ と $P_{i i}$ の関数であ ろから， $\beta$ も当然 $\alpha$ と $P_{i i}$ の関数て (7) 式の関係にある ことがわかる。このことはポリマーの立体規則性，一な わち, triadのタクチシティがこれら三つのパラメーター の中の二つで表わせることを意味している。これらパラ

$$
\beta=\frac{1-P_{i i}}{1-P_{i i} \alpha}
$$

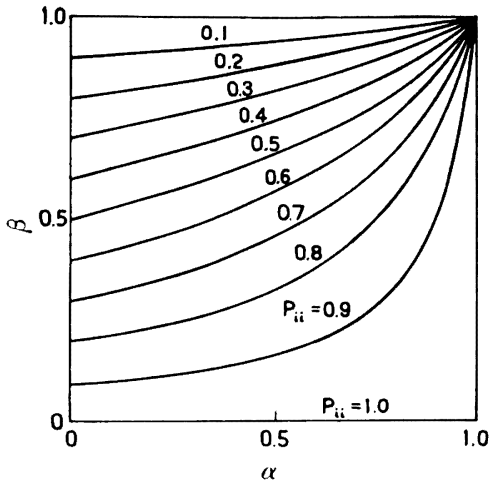

Fig. 1. Relationship between $\alpha$ and $\beta$ under the constant value of $P_{i i}$ (calculated from eq. (7)).

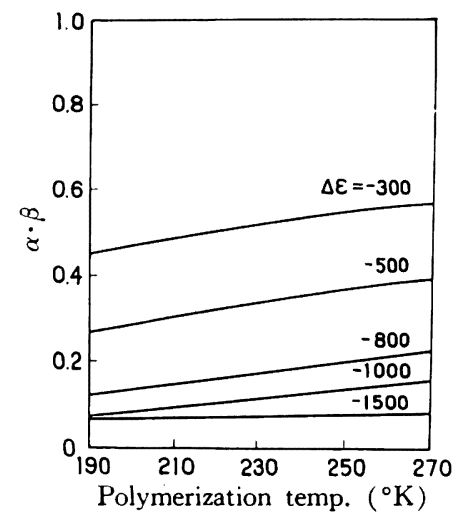

Fig. 2. Relationship between polymerization temperature and $\alpha \cdot \beta$ under the constant value of $\Delta \varepsilon$ (calculated from eq. (8)).

メーターの相互の関係を Fig. 1 に示した。

$\alpha$ および $\beta$ をパラメーターとすると $\Delta \varepsilon$ についての (2)式は (8)式で示される。 $\Delta \varepsilon$ と同栐に $\alpha$, および $\beta$ が重 合温度にどのように依存するかは興味ある問題である。 普通に重合の行なわれる室温から $-80^{\circ} \mathrm{C}$ の筙囲では， $\Delta \varepsilon$ の值に応じて $\alpha \beta$ は Fig. 2 に示すような変化をする ことが(8)式から推定される。

$$
\Delta \varepsilon=-R T \ln \left\{\frac{1}{(\alpha \beta)}\right\}
$$

\section{3. 前末端基効果の実在性についての実験結果}

前に述べたように各種パラメーターの関係が明らかに されたので, 彷来, 報告されている系で前末端基效果が 实在与るかどうか検午した。從来の報告で十分でないも のはここで実験を行なった。 $\alpha \mathrm{MS}, \mathrm{MVE}$ ，および MMA について一定の $\alpha$ 值が得られることがあることを前報2 で知ったのでここれらの系での前末端基効果の実在性を (2)式に良って検时した。 
$\alpha \mathrm{MS}$ については, $\alpha=1$ で前末端基抆果はなかった2)。 ここでわれわれの結果2), および Braun らの結果5)を(2) 式で検討すると，カチオン重合においてもてニオン重合

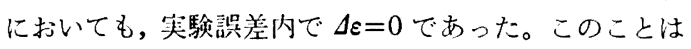
$\alpha=1$ であることから当然である。

MVE は $\alpha=0.75$ であった2)。ここでは, $\mathrm{BF} \cdot \mathrm{O}\left(\mathrm{C}_{2} \mathrm{H}_{5}\right)_{2}$ を触媒としてー78 $0^{\circ} \mathrm{C}$ の範囲で重合を行なった。重公 温度が高くなると, 生成ポリマーのアイソタクチシティ は当然低下してくるが, Fig. 3 に示すように层い温度籁 囲にわたって, $\Delta \varepsilon=-350 \mathrm{cal} / \mathrm{mol}$ とだいたい一定の值を 示した。実験の温度範囲が狭いので, $\Delta \varepsilon$ が温度に無関係 に一定であるかどうか，ここでは結論することはできな いししかし，Fig. 3 のプロットが直線であるこにから，

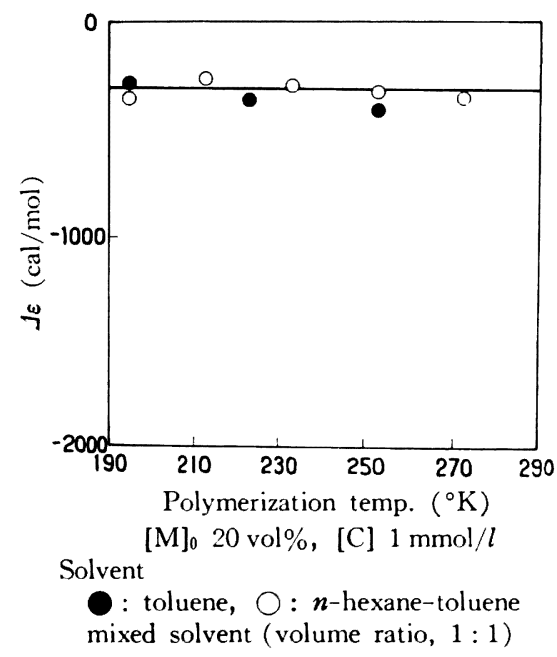

Fig. 3. Relationship between $\Delta \varepsilon$ and polymerization temperature of PMVE obtained by $\mathrm{BF}_{3} \cdot \mathrm{O}\left(\mathrm{C}_{2} \mathrm{H}_{5}\right)_{2}$.

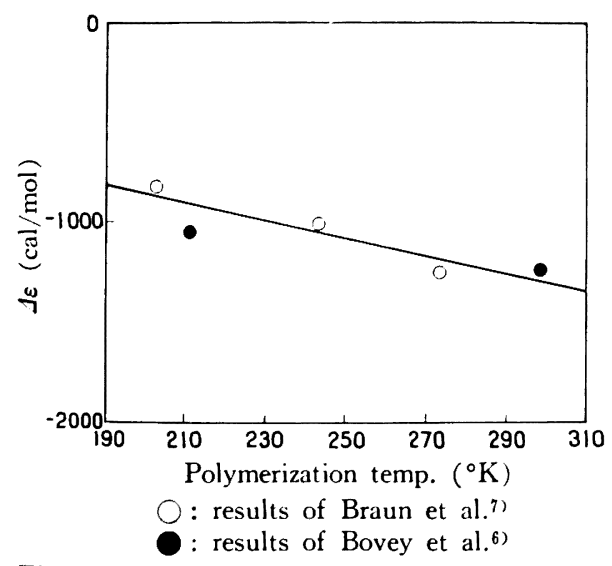

Fig. 4. Relationship between $\Delta \varepsilon$ and polymerization temperature of PMMA obtained by $n$-BuLi in toluene.
前末端基効果がこの系で笑在することはまちがいない。 $\alpha=0.45$ と大きい前末端基効果の存在を暗示した $n$-ブ チルリチウム $(\boldsymbol{n}-\mathrm{BuLi})$ 触媒による MMA の重合につい て, Bovey ら6) および Braun らり) の結果を Fig. 4 に示 した。これらは独立した研究であるが，Fig. 4 に見られ るようにほぼ 1 本の直線で示される。この結果は前末端 基効果がこの系でも実在していることを示している。

メタクリル酸エステルについてはフェニルマグネシウ ムブロマイド $(\mathrm{PhMgBr})$ 触媒による重们が松崎ら ${ }^{8)}$ によ って跟告されている。Fig. 5 に示すように結果はかなり ばらつきがあるが，一応前末端基勃果が実在すると考え て良いであろう。

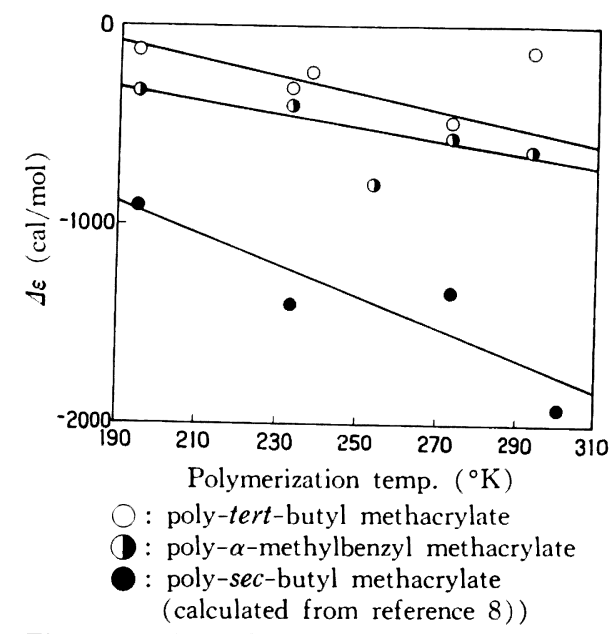

Fig. 5. Relationship between $d \varepsilon$ and polymerization temperature of polymethacrylic esters obtained by $\mathrm{PhMgBr}$ in toluene.

\section{4. イオン重合における前末端基効果と重合 条件の関係}

尙棓でイオン重合に打いて二三の系で前末端基効果が 实在することが明らかとなった。それゆえ，ここでは前 末端基効果に重合条件, 特に試薬の種類がどのように影 響するかを検討した。以下に述べるすべての $\alpha \neq 1$ なる 系で前末端基効果の実在が確認されてはいないが， $\alpha か ゙$ 1より小さいのは前末端基効果によるものであるとして 袚論する。

\section{1 モノマーの種類の影響}

话末端基効果の実在性を見るために，二三のモノマー について， $\alpha$ および $\Delta \varepsilon$ が求められた。その結果をまと めて Table 1 に示した。Table 1 の上部に示したように, 無極性モノマーである $\alpha \mathrm{MS}$ では, どのような触媒を用 いても, 前末端基勃果は認めら机ない。そして, MVEか ら MMA とモノーーの置換基の極性が增すに従って前 末端基効果は增大している。一方, Table 1 の下に示すよ 
Table 1. Relationship between the structure of a monomer and the penultimate effect in the ionic polymerization.

\begin{tabular}{c|c|c|c|c|c}
\hline Monomer & Catalyst & Solvent & $\begin{array}{c}\text { Range of } \\
\text { isotacticity } \\
(\%)\end{array}$ & $\begin{array}{c}\Delta \varepsilon \\
(\mathrm{cal} / \mathrm{mol})\end{array}$ & $\alpha$ \\
\hline$\alpha \mathrm{MS}$ & $\begin{array}{c}\text { Cationic and } \\
\text { anionic catalysts }\end{array}$ & various & $30 \sim 90$ & 0 & 1.0 \\
\cline { 1 - 5 } MVE & $\mathrm{BF}_{3} \cdot \mathrm{O}\left(\mathrm{C}_{2} \mathrm{H}_{5}\right)_{2}$ & various & $40 \sim 60$ & -350 & 0.75 \\
\hline MMA & $n-\mathrm{BuLi}$ & toluene & $80 \sim 90$ & $\begin{array}{c}-1200 \\
\left(\text { at } 0^{\circ} \mathrm{C}\right)\end{array}$ & 0.45 \\
\hline
\end{tabular}

$\Delta \varepsilon(\mathrm{cal} / \mathrm{mol})$ in the anionic polymerization of methacrylic esters by $\mathrm{PhMgBr}$ at $0^{\circ} \mathrm{C}$ in toluene ${ }^{8)}$

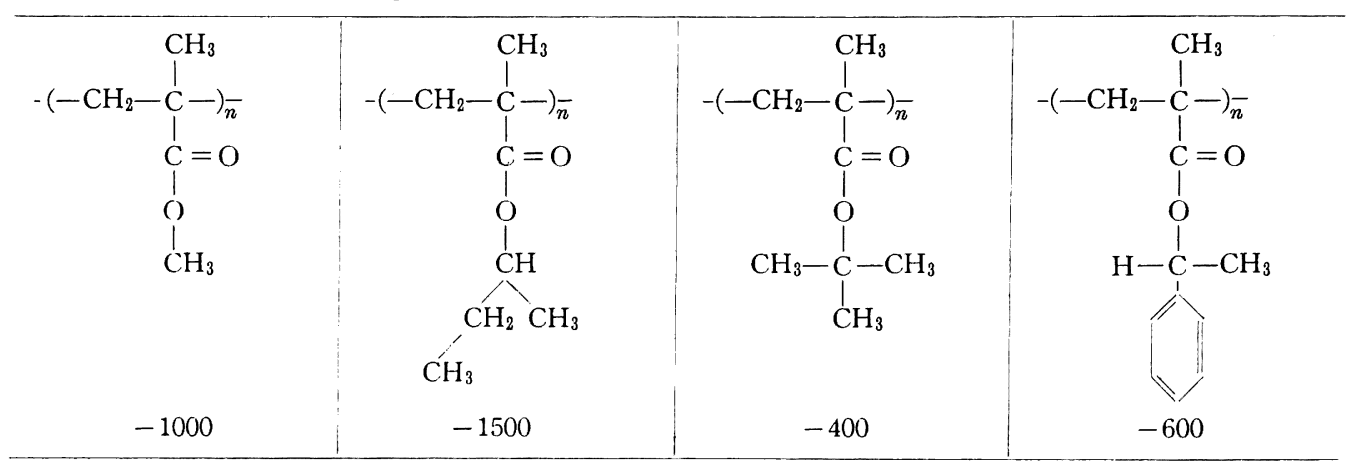

うにメタクリル酸エステルの重合では，エステル基の 分枝が多くてかさ高くなると前末端基効果が減少する傾 向にある。このことはメタリリル酸エステルのアニオン 重合では，前末端基効果が置換基のかさ高さによる立体 的な反発に基くものでないことを示している。

\section{2 触媒の影響}

$\alpha \mathrm{MS}$ では触媒の種類を变えても前末端基効果は認め られなかった。また，MVEについては現在まで触媒の 種類を変えて triad のタクチシティを求めた研究は少な く，触媒の種類によって前末端基効果が影響されるかど うか結論することはできない。

MMA については同一条件で，触媒としてのアルキル アルカリのアルカリ金属の種類を变えた重合が行なわれ ており，対カチオンの影響を見ることができる。Braun らクの結果を計算して Table 2 に対力チオンの影響をま とめた。Braun らは $0^{\circ} \mathrm{C}$ と $-60^{\circ} \mathrm{C}$ で触媒の影響を榆討 しているがここでは $0^{\circ} \mathrm{C}$ の結果を示した。

トルエン中のアイソタクチック重合の結果を Table 2 か ら見ると, 対カチオンが $\mathrm{Li}^{+}$の場合, $I$ フラクションがい らばん多い PMMA が得られ，前末端基効果も他の $\mathrm{Na}^{+}$ および $\mathrm{K}+$ に対していちばん大きい。これは先のモノマ 一の構造から推定されたように前末端基効果が置換基間 の反発によるものでなく，触媒と前末端基の極性置換基 (カルボニル基)との相互作用によることを示している。 この場合，先にも述べたように， $\alpha$ オ゙小さく前末端基効
Table 2. The effect of the kind of a counter-cation (alkali metal) of the penultimate effect of the stereospecific polymerization of MMA. ${ }^{7)}$

\begin{tabular}{c|r|c|c|r|r|r}
\hline Solvent & \multicolumn{3}{|c|}{ Toluene } & \multicolumn{3}{c}{ Pyridine } \\
\hline tacticity & $\begin{array}{c}I \\
(\%)\end{array}$ & $\begin{array}{c}S \\
(\%)\end{array}$ & $\begin{array}{c}H \\
(\%)\end{array}$ & $\begin{array}{c}I \\
(\%)\end{array}$ & $\begin{array}{c}S \\
(\%)\end{array}$ & $\begin{array}{c}H \\
(\%)\end{array}$ \\
\hline $\mathrm{Li}^{+}$ & 72.0 & 10.7 & 17.3 & 8.2 & 60.0 & 31.8 \\
$\mathrm{Na}^{+}$ & 56.7 & 12.4 & 30.9 & 11.9 & 42.3 & 45.8 \\
$\mathrm{~K}^{+}$ & 34.6 & 23.3 & 42.1 & 14.0 & 33.1 & 52.9 \\
\hline parameter & $\begin{array}{c}\Delta \varepsilon \\
(\mathbf{c a l} / \mathrm{mol})\end{array}$ & $\alpha$ & $\beta$ & \multicolumn{1}{c|}{$\Delta \varepsilon$} & $\alpha$ & $\beta$ \\
\hline $\mathrm{Li}^{+}$ & -1250 & 0.48 & 0.19 & -350 & 0.62 & 0.83 \\
$\mathrm{Na}^{+}$ & -600 & 0.70 & 0.48 & 0 & 1.0 & 1.0 \\
$\mathrm{~K}^{+}$ & -300 & 0.75 & 0.17 & +200 & 1.3 & 1.2 \\
\hline
\end{tabular}

果の大きい系では $\beta$ も小さいことは注目すべきである。 また,ピリジン中のシンジオタクチック重合においても, $\mathrm{Li}^{+}$対カチオンでは $S$ フラクションが多い PMMAを生 じ，この場合も前末端基効果が大きいことは興味深い。

\section{3 溶媒の影響}

$\alpha \mathrm{MS}$ についてはここで用いた溶媒の範囲では， $\alpha=1$, $\Delta \varepsilon=0$ であって，前末端基効果は認められなかった。

上述のようにイオン重合における前末端基効果がすべ て触媒から生じた対イオンと前末端基の極性基との相互 作用であるとするならば，刘イオンを溶媒和するような 


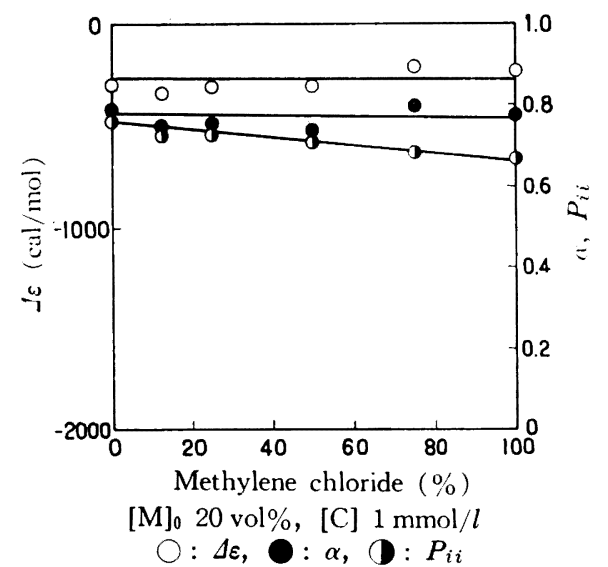

Fig. 6. Relationship between a solvent composition and $\Delta \varepsilon, \alpha$ or $P_{i i}$ of PMVE obtained by $\mathrm{BF}_{3} \cdot \mathrm{O}\left(\mathrm{C}_{2} \mathrm{H}_{5}\right)_{2}$ in toluene-methylene chloride mixed solvents at $-78^{\circ} \mathrm{C}$.

溶媒を用いると前末端基効果汢減少するはずである。溶 媒によって注子想どおり少量の添加で前末端基勃果の大 きく変化するものもあるが，他方，ポリマーの立体规则 性を低下しても， $\alpha や \Delta \varepsilon$ の倠を大きく変光ない上こつ の溶媒もある。

$\alpha=0.75, \Delta \varepsilon=-350 \mathrm{cal} / \mathrm{mol}$ と比較的前末端基効果の 小さかった $\mathrm{MVE}-\mathrm{BF}_{3} \cdot \mathrm{O}\left(\mathrm{C}_{2} \mathrm{H}_{5}\right)_{2}$ 系の重合で, 無極性淮 媒であるトルエンに極性溶媒である塩化メチレンを加え ると, $P_{i i}$ は隇少するが， $\alpha$ 拉よび $\Delta \varepsilon$ は Fig. 6 に示すよ うにあまり大きく変化しない。このことは次の二つの事 実のいずれかによるものであろう。一つ注前末端基効果 が対了ニオンと前末端基のメトキシ基との強い相互作用

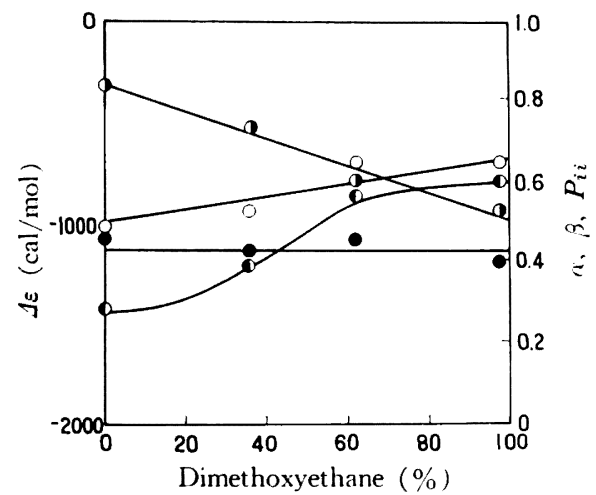

$[\mathrm{M}]_{0} 1 \mathrm{~mol} / l$, [C] $0.06 \mathrm{~mol} / l$ (calculated from reference 7 ))

$\bigcirc: \Delta \varepsilon, \bigcirc: \alpha, \boldsymbol{D}: \beta, P_{i i}$

Fig. 7. Relationship between a solvent composition and $\Delta \varepsilon, \alpha, \beta$ or $P_{i i}$ of PMMA obtained by $n-\mathrm{BuLi}$ in toluene-dimethoxyethane mixed solvents at $-78^{\circ} \mathrm{C}$.
に上うものでないか，もう一つは隍化メチレンが生脣末 端の炭督力チオンを溶媒和して $P_{i i}$ は小さくするが刘イ オンを十分溶媒和できないということである。今のとこ ろこのいず机であるかを泌定することはできなかった。 一う; MMAのフニオン而合では種々の興味ある場合 が存在する。MMAの $n$-BuLiによるトルエン中の重公 では，極性溶媒であるジメトキシェタン，ピリジンおよ びテトラヒドロフラン(THF)を加克ると,Iフラクショ ンが減少して $S$ フラクションが增加する7゙,9)。この場公, ジメトキシェタンをトルェンに添加してゆくど), Fig.7 に示与ように $P_{i i}$ は隇少するが $\alpha$ は一定であった。この

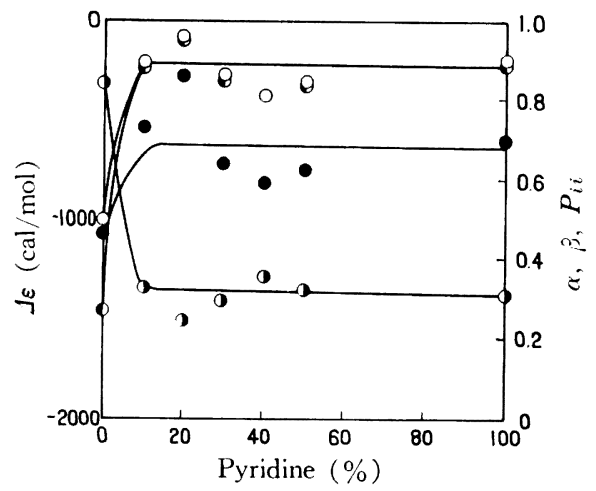

$[\mathrm{M}]_{0} 1 \mathrm{~mol} / l, \quad[\mathrm{C}] 0.06 \mathrm{~mol} / l$ (calculated from reference 7 ))
$\bigcirc: \Delta \varepsilon$,
, D: $\beta, \mathcal{D}: P_{i i}$

Fig. 8. Relationship between a solvent composition and $\Delta \varepsilon, \alpha, \beta$ or $P_{i i}$ of PMMA obtained by $n$-BuLi in toluene-pyridine mixed solvents at $-30^{\circ} \mathrm{C}$.

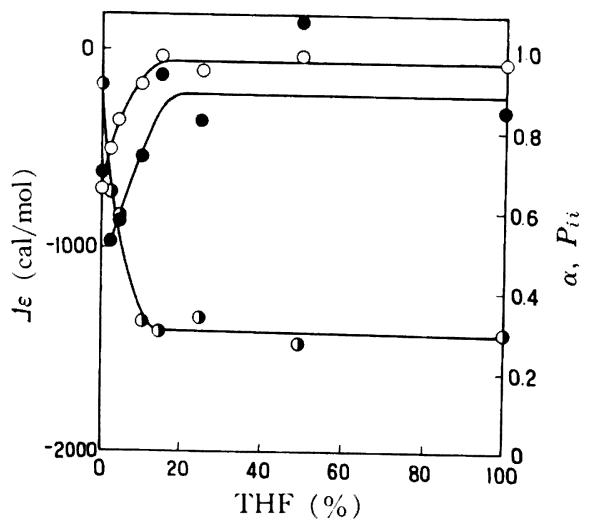

$[\mathrm{M}]_{0} 0.6 \mathrm{~mol} / l, \quad[\mathrm{C}] 0.02 \mathrm{~mol} / l$ (calculated from reference 9$)$ ) $\bigcirc: \Delta \varepsilon, \bigcirc: \alpha, \boldsymbol{\top}: P_{i i}$

Fig. 9. Relationship between a solvent composition and $\Delta \varepsilon, \alpha$ or $P_{i i}$ of PMMA obtained by $n$ - $\mathrm{BuLi}$ in toluene-tetrahydrofuran mixed sol. vents at $-78^{\circ} \mathrm{C}$. 
結果， $\beta$ は增加することにな るが, $\Delta \varepsilon$ の溶媒による変化は 少ない。トルエンはピリジ ンク，敊よび $\mathrm{THF}^{9}$ を加える と, Fig. 8, および Fig. 9 に 示与ように, 少量の極性溶媒 の添加によって $P_{i i}$ も前末端 基効果も減少する。ジメトキ シェタンと異なりこれらの極 性溶媒の添加は, $\alpha$ も $\beta$ も, ともに变化せしめている。

このような溶媒の影響の症 は，たら゙え溶媒が対カチオン のアルカリ金属を強く溶媒和 するかどうかにかかっている のであ万う。ピリジンはジメ トキシエタンより丁ルカリ金 属に対する溶媒和が強いとい うこレは十分考えられるところである。しかし，トルェ ンにジメトキシェタンを添加したときに， $\beta$ のみ変化し て $\alpha$ は変化しないという理由については現在のところ不 明である。

\section{4 シンジオタクチック重合における前末端基効果}

彷来，イオン重合でも遊離イオンに近い状態あるいは solvent separated ion-pair といった刘イオンの影留が少 ない状態で低温重台を行なうと，ラジカル重合と同じく シンジオタクチックポリマーが得られると考劣られてき た。しかし，Table 2, 打よび，その他の実験結果から MMA のアニオン重合では一般に $\alpha$ が小い前末端基效 果の大きい重合系の坊がシンジオタクチックポリーーが 生じやすいことが結論される。換言すればアインタクチ ックポリマーはステレオブロックで，シンジオタクチッ クポリマーはランダムであるという從来の考方方に対し て，PMMA では，いずれの場合もステレオブロックに なりやすいということができる。こうなると対イオンが 全く関与しない完全な遊離イオンによる重合よりも，む しろ刘イオンがなえらかの形で生長ポリマーと相互作用 のある系の片がシンジオタクチックポリマーを生じやす いということになる。この点はシンジオタクチックポリ マ一の合成にも閣連して，今後解明せね枯ならない重要 な問題である。しかし，現在 MMA のアニオン車公につ いての結果があるだけでありこここでは問題を提起する にとどめておく。

\section{5. 結語}

以上の結果をまとめると Table 3 に示すようになる。 果のように均一系触媒による重合において，前末端基効 この存在寸る多くの系が涊めら机た。そして槚性溶媒の
解末端基効果に対する影響の仕方より考えて，MMA の アルキルアルカリ触媒による重合では，前末端基効果は 刘イオンと前末端基の相互作用ということができる。し かし，MVEのカチオン重合では，極性溶媒を加えても 前末端基効果は変化しない。このことは対イオンには無 関係に前末端基のみによる前末端基効果の存在すること を示している。

MMA のアイソタクチック重合については上記の前末 端基効果を考虑した反応機構のモデルが提出されてい る10)。しかし，これらのモデルでは $\beta<1$ ，すなわち，シ ンジオタクチック結合の次にシンジオタクチック付加が 起こりやすいこいう条件は满足されていない。これは朔 末端基勃果を考虑したシンジオタクチック重合の機棈と ともに将来に残された問題である。他方，MVE のカチ オン重合での対イオンの関与しない前末端基効果につい ては，先にわれわれの提出した反応機棈のモデル11がつ ごうが良い。しかし，このモデルも二重結合のシス開鎖 とトランス開鎖の問題が解決されておらず，MMAの丁 ニオン重分と同様に今後の問題として残されている。

付記：本研究を行なうにあたり，種々ご教示をい ただいた呉羽紡高柣研究所の中条利一郎博士に感謝し ます。

\section{文献}

1) 古川淳二：工化, 68, 763 (1965)

2) Y. Ohsumi, T. Higashimura, S. Okamura: $J$. Polymer Sci., A4, 3729 (1965)

3） R. Chujo: J. Phys. Soc., Japan, B, 投稿中; 大 隅行彦, 東村敏延, 岡村誠三, 中条利一郎, 恢滕 至郎, 長井栄一：第14回高分子討論会要旨集, 73 (1965) 
4) A. Miyake: Repts. Prog. Polymer Phys. Japan, 5, 257 (1962)

5) D. Braun, G. Heufer, U. Johnsen, K. Kolbe: Ber. der Bunsengesellschaft, 38, 959 (1964)

6) F. A. Bovey, G. V. D. Tiers: J. Polymer Sci., 44, $173(1960)$

7) D. Braun, M. Herner, U. Johnsen, W. Kern: Makromol. Chem., 51, 15 (1962)
8）松崎 啓, 不田 彰, 館野紀昭, 朝倉忠雄, 長谷川 章, 為田周明: 工化, 68, 852 (1965)

9）結城平明，太田浩二，烟田耕一，村橋俊介：第14 回高分子瀜会要旨第，67 (1965)

10）たと总ば, C. E. H. Bawn, A. Ledwith：Quart Rev., 16, 361 (1962)

11) T. Higashimura, T. Yonezawa, S. Okamura, K. Fukui: J. Polymer Sci., 39, 487 (1959)

\title{
Existence of the Penultimate Effect in Homogeneous Stereospecific Polymerization and the Relationship between Polymerization Condition
}

\author{
By Yukihiko Ohsumi*, Toshinobu Higashimura* and Seizo Okamura*
}

The penultimate effect in the stereospecific polymerization by the homogeneous ionic mechanism is studied by using $\alpha$-value $\left(P_{s i} / P_{i i}\right)$ which is the ratio of the probability of a triad isotactic addition $\left(P_{i i}\right)$ and that of a triad heterotactic addition $\left(P_{s_{i}}\right)$. The relationship between $\alpha$-value and the free energy difference of stereoregular addition and heterotactic one is calculated. From Chujyo's treatment, it is clarified the penultimate effect truly exists in the case of the cationic polymerization of methyl vinyl ether (MVE) and the anionic polymerization of methyl methacry. late (MMA).

After the existence of the penultimate effect was confirmed in the ionic polymerization, the relation between the polymerization conditions and the penultimate effect is studied. In the cationic polymerization of MVE a polar solvent does not affect the penultimate effect. Otherwise, in the anionic polymerization of MMA a polar solvent decreases the penultimate effect. From these results, it is estimated that two kinds of the penultimate effect exist in the ionic polymerization; one is mainly due to the interaction between a counter-ion and a penultimate group and the other is due to only the repulsion of the penultimate group and the incoming monomer irrespective of a counter-ion.

\footnotetext{
* Department of Polymer Chemistry, Kyoto University (Yoshida, Sakyo-ku, Kyoto)
} 